\title{
Development of a Structured Situational Interview or Multiple Mini Interview (MMI) for the Pre-Residency Assessment System in a Tertiary General Hospital in the Philippines
}

\author{
Francisco P. Tranquilino \\ Section of Cardiology, Department of Medicine, College of Medicine and Philippine General Hospital, University of the Philippines Manila
}

\begin{abstract}
Background. Numerous selection criteria have been developed to assess the appropriate attributes and behavior expected of an Internist. The traditional personal interview format, however, cannot sufficiently evaluate professionalism competency and it has a low reliability and validity.

Objectives. This study will conduct an extensive review and describe the existing interview portion of the residency selection process of the UP-PGH Department of Medicine and attempt to develop an effective structured multiple mini interview to replace the traditional format.
\end{abstract}

Methods. Review of Department records and consultant interviews will be conducted prior to the development of the new structured situational interview.

Results. An MMl has been developed consisting of 6 domains evaluated in separate stations. Each domain pertains to an attribute or behavior deemed important in the resident's professional career, namely honesty, teamwork, respect for authority, time management, ethical behavior on the use of emerging technologies and in dealing with the pharmaceutical industry. A 5-point evaluation system will determine the interviewee's appropriateness and acceptability of behavior.

Conclusion. An MMl has been developed to evaluate appropriateness of behavior when presented with actual situations that may occur on-the-job.

Key Words: multiple mini-interview, situational interview, residency program
Corresponding author: Francisco P. Tranquilino, MD

Section of Cardiology

Department of Medicine

Philippine General Hospital

University of the Philippines Manila

Taft Avenue, Ermita, Manila 1000 Philippines

Telephone: +6325264372

Email: ftranquilino@yahoo.com

\section{Introduction}

Admission into an Internal Medicine Residency Program is a highly competitive process. Various selection criteria have been devised in order to assess appropriate attributes and behavior that will measure the expected competencies of an Internist. Some of these attributes are measured through the applicant's academic performance, examination, clinical performance, research output, etc. An important aspect, however, that is difficult to evaluate noncognitive variables which may include interpersonal skills, integrity and professionalism. The attributes associated with these domains are a growing concern and usually, the assessment is situation or context dependent.

Interviews are a valued part of admissions procedures in medical school and in Residency Program selection. ${ }^{1}$ However, traditional interview format and content varies considerably. It lacks consistency in approach among the interviewers, where different questions may be asked from different applicants and it lacks reliability when same questions are asked and interviewers may disagree on the appropriateness and desirability of answers. ${ }^{2}$ It is not unusual for this type of process to have such a low level of reliability and validity. More frequently, it consists of questions that are irrelevant to the job and is in no way a good indicator of how one will eventually perform. In the end, articulate applicants may perform well and interviewers may favor such candidates.

Moreover, in the traditional interview, professionalism competency is insufficiently evaluated. In recent years, a multi-station interview system called the Multiple Mini Interview (MMI) has been developed at the Michael G. DeGroot School of Medicine at McMaster University in Hamilton, Ontario, Canada. This instrument has demonstrated evidence for generalizability and validity in relation to future clinical and licensing examination performance as compared to the traditional interview methods. ${ }^{1}$ More importantly the flexibility of MMI allows the selection of applicants whose behavior aligns with the intended professionalism competency. Meanwhile, professional potential is derived from medical professionalism theory and that professional behavior is context specific or situation dependent. ${ }^{3}$ This would mean that one specific aspect of professional behavior differ from 
one situation to another. These various situational context, therefore, are utilized to predict the behavior in a particular setting.

\section{Objectives}

It is the study's general objective to develop an effective structured MMI for the Pre-Residency Assessment System. Specifically, it aims to conduct an extensive review of and describe the existing interview portion of the Pre-Residency Assessment System in the selection of first year residents at the University of the Philippines-Philippine General Hospital (UP-PGH) Department of Medicine.

\section{Significance of the Study}

A structured MMI will reduce potential bias and subjectivity of the traditional process of applicant assessment. It will also increase consistency and reliability of the process by providing a series of pre-determined, hypothetical and task-related questions. Because the questions are based on work situations and contents relevant to the job, the questions have high face validity; they appear relevant which increases the interviewees' motivation during the interview. Finally, the new criteria may allow for better evaluation of a candidate's non-cognitive variables (e.g. interpersonal skills, integrity and medical professionalism or professional behaviour).

\section{Methods}

A review of published literature on the topic was conducted through PubMed/MEDLINE using the following search words: residency program, situational interview, resident selection, medical education. The identified related citations and the bibliography of related articles were also used. All records and documents from the UP-PGH Department of Medicine pertaining to the residency assessment, evaluation and selection were retrieved, reviewed and described. Interviews with consultants in the Department was conducted whenever possible. Their comments regarding the residency selection process were elicited. Using the collated material, the author developed a new Structured Multiple Mini Interview Process.

\section{Results}

\section{The Internal Medicine Residency Training Program of the UP-PGH Department of Medicine}

The Residency Training Program in Internal Medicine (IM) offered by the UP-PGH Department of Medicine is the only program of its kind in the Philippines with full accreditation from the Philippine College of Physicians (PCP) thru its rigorous evaluation process. This PCP standardization process has the ultimate purpose of producing compassionate and competent internists who will be taking care of the health of the Filipinos. ${ }^{1}$
The program is a three-year Residency Course to attain excellence and relevance in Internal Medicine through the implementation of effective training, service and research unique to the Philippine General Hospital setting. In 2004, the objectives of the program were redefined and after a careful re-evaluation, the Executive Committee under its Department Chairman Dr. Agnes D. Mejia decided to embark on an ambitious restructuring of the entire residency training curriculum. Guided by the specific requirements of the PCP but taking into full consideration the PGH environment, a new program was developed, unique in some aspects from that prescribed by the PCP. Some of the major changes were:

1. Revision in the Subspecialty Rotations including changes in duration of the major specialties such as Cardiology and Pulmonary Medicine whose required 6 weeks rotation was lowered to 4 weeks. This change was justified after a careful consideration of the types of patients being seen by the residents in other service areas such as the Pay Wards and the Critical Care areas (e.g. Medical Intensive Care Unit and the Central ICU).

2. The creation of separate rotations in Adult Medicine, Toxicology, Research and Electives

3. Maximizing exposure to the Pay Wards in order to learn from the different management styles of the Consultants from various specialties.

4. Consolidation of the different conferences to maximize consultant participation and the inclusion of different topics in these conferences suitable to each year level as well as non-medical topics.

5. Creation of time-protected Residents' Continuity Clinic and its subsequent incorporation with the "New Patients" Clinic in the Out-patient Department (OPD), which is based on the principles of "continuity of care" and "primary care physicians."

6. Computerization of the OPD patient records in order to improve scheduling of follow-ups, charting and census.

7. Closer coordination between Residents and Fellows in the management of cases in all service areas.

8. Increased Consultant supervision in all training and service areas.

9. Re-evaluation of the Pre-Residency Assessment System that is being used in the screening and acceptance of new residents

Admission into this Program is a highly competitive process. The Selection Process that has been utilized over the years consists of: (a) Pre-Pre-Residency Evaluation Summary which includes Academic Performance (50\%), Clinical Performance (20\%) and Department-administered Examination (30\%); (b) Pre-Interview Evaluation Summary 
(80\%) consisting of the Pre-Pre-Residency Score (20\%) and Pre-Residency Performance Evaluation (60\%) and the Interview Score (20\%).

The Interview portion, however, does not follow a standard procedure except that some key elements were identified and must be determined from the applicant's responses pertaining mainly to Research Potential (6\%), Commitment to Service (6\%), Communication Skills (5\%) and Personality (3\%). It lacks reliability because interviewers rarely ask the same questions to the applicants. In occasional instances, when same questions are asked, there is no agreement on the appropriateness of the answers. Because of these inherent defects in the process, a candidate's score may eventually still be attributable to chance. A candidate assigned to a like-minded interviewer may score better than one assigned to an incompatible or difficult interviewer. ${ }^{4}$

The experiences in the Department of Medicine during the past years have shown problems with Residents' attributes associated with medical professionalism and professional behavior (e.g. dishonesty, time management concerns, dealing with patient's relatives, teamwork, dealing with Residents from other Departments), relationship with the pharmaceutical industry, et cetera. It is therefore important to predict how the Resident will behave under these circumstances once they have been accepted into the training program.

Identification of characteristics deemed to be important and highly associated with medical professionalism was made (Table 1). These included: honesty, teamwork, respect for authority, time management, managing change and stress, ethical behavior on the use of emerging technologies (e.g. professional conduct in the use of the social media), ethical behavior in dealing with the pharmaceutical industry, ability to accept feedback about one's self and ability to accept limitation (e.g. professional limitations).

Table 1. Structured situational interview or MMI

Set A. Honesty, Teamwork \& Respect for Authority

\begin{tabular}{|c|c|c|c|}
\hline Characteristics & Honesty & Teamwork & Respect for Authority \\
\hline Situation & $\begin{array}{l}\text { You are in the OPD for your scheduled } \\
\text { Continuity Clinic. Your next patient is Mr. } \\
\text { Reyes, 56M, known hypertensive and diabetic. } \\
\text { Patient presenting now for chest pain which he } \\
\text { already complained about during his prior } \\
\text { consultation with you } 2 \text { days ago. On review of } \\
\text { his chart, you noted his ECG showing acute } \\
\text { injury pattern which was done during the } \\
\text { previous consult but you failed to take note of } \\
\text { and therefore unable to institute appropriate } \\
\text { intervention. } \\
\text { What do you say to Mr. Reyes? Why? }\end{array}$ & $\begin{array}{l}\text { During your duty as POD II, you received a } \\
\text { referral at the Emergency Room from the ER } \\
\text { Resident. The patient being referred to you was a } \\
68 M \text { presenting with dyspnea and 2-pillow } \\
\text { orthopnea. The initial impression was Pneumonia } \\
\text { for which IV antibiotic was already started. } \\
\text { Nebulization and O2 support were also instituted. } \\
\text { On the patient's } 6^{\text {th }} \text { hour at the ER, dyspnea } \\
\text { became progressive and he was subsequently } \\
\text { intubated. The patient is now being referred to } \\
\text { you for further evaluation and possible transfer to } \\
\text { MICU. However, your own history and PE made } \\
\text { you to revise the impression to heart failure. You } \\
\text { managed the patient with anti-HF regimen and he } \\
\text { improved after aggressive diuresis which you } \\
\text { instituted. } \\
\text { How will you handle this situation and how will } \\
\text { you deal with the DER Resident? }\end{array}$ & $\begin{array}{l}\text { During your Orientation to the Residency } \\
\text { Program of the Department, you were } \\
\text { provided a copy of the Department's } \\
\text { Training Handbook for Residents and } \\
\text { Fellows. However, on your } 3^{\text {rd }} \text { month of } \\
\text { training, you were informed by your } \\
\text { Chief Resident that in conjunction with } \\
\text { the Department's prioritization of the } \\
\text { Continuity Clinic and upon the } \\
\text { recommendation of the Training } \\
\text { Committee, the Executive Committee } \\
\text { reclassified "Failure to be physically } \\
\text { present at the OPD } 30 \text { minutes from the } \\
\text { start of official clinic time," from a } \\
\text { Minor Infraction to a Grave Offense } \\
\text { which carries with it a corresponding } \\
\text { sanction of } 24 \text {-hour Pay Duty. } \\
\text { What will you do? }\end{array}$ \\
\hline Probes & $\begin{array}{l}\text { How will you explain to the patient what } \\
\text { has happened? } \\
\text { How will you respond if the patient } \\
\text { became angry? } \\
\text { How will you address logistical issues? } \\
\text { SOPs in releasing results in the OPD, } \\
\text { charting/availability of charts, following-up } \\
\text { results, etc. }\end{array}$ & $\begin{array}{l}\text { How will you deal with the ER Resident? } \\
\text { How will you call his attention to the wrong } \\
\text { initial impression? } \\
\text { - Will you take this opportunity to teach the ER } \\
\text { Resident on the proper diagnosis of HF? } \\
\text { - Will you elevate this concern with your } \\
\text { Seniors? Chief Residents? Consultants? }\end{array}$ & $\begin{array}{l}\text { - How will you show your objection or } \\
\text { react to this change? } \\
\text { - } \quad \text { Accept the change or not? } \\
\text { - } \quad \text { Propose compromises? }\end{array}$ \\
\hline $\begin{array}{l}\text { Primary } \\
\text { Objectives }\end{array}$ & Honesty & $\begin{array}{l}\text { Ability to avoid reprimanding a colleague for } \\
\text { the misdiagnosis. }\end{array}$ & Show respect for authority \\
\hline $\begin{array}{l}\text { Secondary } \\
\text { Objectives }\end{array}$ & $\begin{array}{l}\text { Continuity of care, physician-patient } \\
\text { relationship, hospital } \\
\text { SOPs }\end{array}$ & $\begin{array}{l}\text { Recognize the acceptable venues in discussing } \\
\text { similar occurrences (e.g. when to elevate the issue } \\
\text { to Seniors and/or Consultants), harmonious } \\
\text { interaction with colleagues from other } \\
\text { Departments }\end{array}$ & $\begin{array}{l}\text { Managing change. Accept that changes in } \\
\text { the Department's priorities are being } \\
\text { considered and changes need to be } \\
\text { implemented for improvement of services. } \\
\text { Welfare of patients above personal } \\
\text { interests must be demonstrated. }\end{array}$ \\
\hline Rationale & $\begin{array}{l}\text { Designed to test whether or not the applicant } \\
\text { will admit that a mistake has been made. } \\
\text { Honesty is one of the most important attributes } \\
\text { of physicians but usually taken for granted by } \\
\text { patients, peers and colleagues. This attribute } \\
\text { may instill trust at all levels of medical practice. }\end{array}$ & $\begin{array}{l}\text { Harmonious and effective interaction with peers, } \\
\text { colleagues and co-workers is key to a more } \\
\text { effective delivery of healthcare intervention to } \\
\text { patients. }\end{array}$ & $\begin{array}{l}\text { Respect for professional authority based } \\
\text { on knowledge and expertise must always } \\
\text { be for the benefit of the patients. }\end{array}$ \\
\hline
\end{tabular}




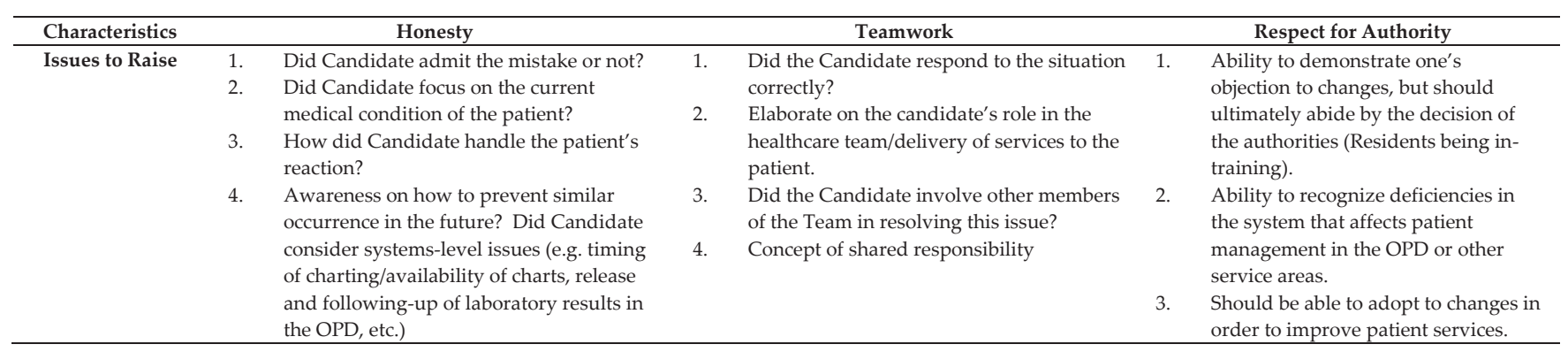

Set B. Time management, Ethical behavior on the use of emerging technologies \& Ethical behavior in dealing with pharmaceutical companies

\begin{tabular}{|c|c|c|c|}
\hline Characteristics & Time management & $\begin{array}{l}\text { Ethical behaviour on the use of emerging } \\
\text { technologies (e.g. professional conduct in } \\
\text { the use of social networking, etc.) }\end{array}$ & $\begin{array}{l}\text { Ethical behaviour in dealing with } \\
\text { Pharmaceutical companies }\end{array}$ \\
\hline Situation & $\begin{array}{l}\text { It is the Department's policy that every Thursday } \\
\text { 9-10am is protected time and everyone is required } \\
\text { to attend the Audit Conference at Guazon Hall. } \\
\text { Continuity clinic is also a priority although on } \\
\text { Thursdays, Residents are allowed to start their } \\
\text { OPD clinic at 10am. } \\
\text { During your rotation at the Pay Service on a } \\
\text { Thursday, you were informed by the NOD that a } \\
\text { patient by a GI Consultant assigned to your floor } \\
\text { has been scheduled for abdominal CT-scan in MDH } \\
\text { at 9:30am and that you are expected to accompany } \\
\text { the patient. This schedule, however, conincided } \\
\text { with the Audit Conference and your Continuity } \\
\text { Clinic at 10am. In addition, your other co- } \\
\text { Residents at the Pay Floors are busy conducting } \\
\text { other patients as well. What will you do? }\end{array}$ & $\begin{array}{l}\text { As your way of relieving stress, you usually } \\
\text { go on-line and chat with your friends thru } \\
\text { your Facebook account. On your Wall, you } \\
\text { usually exchange stories about how the day } \\
\text { went for you. On this specific day, on } \\
\text { opening your "public" Wall, you already } \\
\text { noted several exchanges of rants among your } \\
\text { friends and co-Residents. You read this on } \\
\text { your wall: } \\
\text { Resident A: "Toxic ang araw ko! Badtrip ang } \\
\text { duty sa ER, daming patients." } \\
\text { Resident B: "Toxic din sa OB-AS kagabi." } \\
\text { Resident A: "Walang hihigit pa sa DEMS, } \\
\text { palpak si Dr. J. Jemon, may referral sa akin, } \\
\text { pneumonia daw, pag-examine ko CHF pala. } \\
\text { Ayun, hindi ko nahabol ang fluids, na- } \\
\text { intubate." } \\
\text { Resident C: "What else is new sa ER, walang } \\
\text { pag-asa mga tao dyan." } \\
\text { Resident B: "Hows the patient? Buhay pa?"” } \\
\text { Resident A: "Syempre binuhay ko." } \\
\text { Resident D: "Bravo! Buti na lang nasa Neuro } \\
\text { ako this month." } \\
\text { How will you join this ranting on your } \\
\text { Facebook Wall? What will be your first } \\
\text { statement? }\end{array}$ & $\begin{array}{l}\text { You and your Co-Residents assigned } \\
\text { at the Pay Service will be conducting } \\
\text { your monthly Census Conference } \\
\text { with your Consultant Coordinator. } \\
\text { The Consultant is available any day } \\
\text { of the week but only between 11am- } \\
\text { 1pm. Seeing no other possible } \\
\text { alternate dates, you set the } \\
\text { conference on a Friday at } 12 \mathrm{nn} \text {. In } \\
\text { order to impress your Consultant, } \\
\text { you asked your Med Rep-friend to } \\
\text { sponsor your lunch for this } \\
\text { conference. Your friend obliged, } \\
\text { however, on the day of the } \\
\text { conference, upon seeing the } \\
\text { company-sponsored lunch being } \\
\text { served, your Consultant called your } \\
\text { attention saying that it is improper } \\
\text { to solicit sponsorship from the } \\
\text { industry for this purpose. } \\
\text { How will you handle this situation? }\end{array}$ \\
\hline Probes & $\begin{array}{l}\text { What task will you prioritize? Why? } \\
\text { - Will you ask for assistance? From whom? } \\
\text { Candidate decided to attend the Audit } \\
\text { Conference at 9am since the CT-scan is at } \\
\text { 9:30am. However, when she went back to the } \\
\text { Pay Floor at 9:30, the NOD reprimanded } \\
\text { him/her for being late, NOD has been texting } \\
\text { since 8:45 because Ambulance is already } \\
\text { waiting for the patient by then, noting that } \\
\text { since procedure is at 9:30, patient should be on } \\
\text { his way to MDH before that time. To } \\
\text { aggravate matters, relative of patient is } \\
\text { blaming you for cancellation of scan which has } \\
\text { been difficult to schedule in the first place. } \\
\text { How will you handle this situation? } \\
\text { How will you deal with the NOD who is } \\
\text { blaming you for the incident? } \\
\text { How will you handle your patients in the } \\
\text { Continuity Clinic? }\end{array}$ & $\begin{array}{l}\text { Will you join this ranting/conversation? } \\
\text { Why or why not? } \\
\text { Do you find anything inappropriate in } \\
\text { this exchange of statements on } \\
\text { Facebook? } \\
\text { - } \quad \text { go you think there are existing } \\
\text { guidelines on the proper use of social } \\
\text { networking sites? } \\
\text { Is the ranting above ethical? Explain } \\
\text { your answer }\end{array}$ & $\begin{array}{l}\text { Why is this practice of } \\
\text { soliciting Pharma sponsorship } \\
\text { inappropriate? } \\
\text { - How will you react if you } \\
\text { know that in the sub-specialty } \\
\text { society gatherings of your } \\
\text { Consultants, they allow } \\
\text { Pharma-sponsorship? } \\
\text { Are you aware of existing } \\
\text { guidelines on this issue? } \\
\text { Can you cite other } \\
\text { inappropriate behaviour in } \\
\text { dealing with the pharma } \\
\text { industry? }\end{array}$ \\
\hline $\begin{array}{l}\text { Primary } \\
\text { Objective }\end{array}$ & $\begin{array}{l}\text { Prioritization of tasks but informing the other } \\
\text { persons concerned of your plans. }\end{array}$ & $\begin{array}{l}\text { Candidate must be able to determine the } \\
\text { appropriateness of the use of social } \\
\text { networking. What is ethical or not. } \\
\text { Distinguish between professionalism and } \\
\text { personal privacy in social networking sites. }\end{array}$ & $\begin{array}{l}\text { Demonstrate ethical behaviour in } \\
\text { dealing with the Pharma industry }\end{array}$ \\
\hline
\end{tabular}




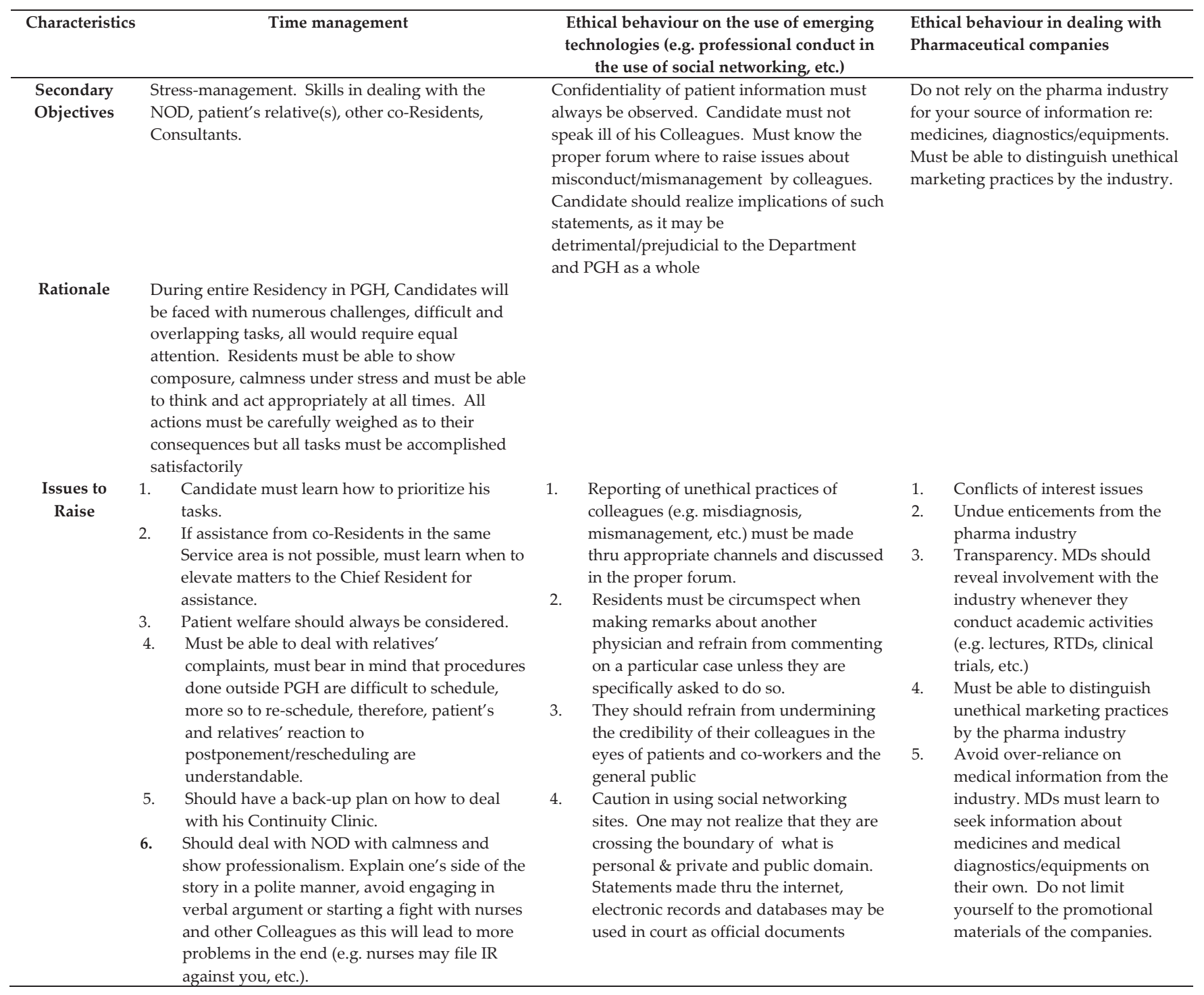

\section{SCORE SHEET}

\begin{tabular}{|c|c|c|c|c|}
\hline 1 & 2 & 3 & 4 & 5 \\
\hline $\begin{array}{l}\text { Does not understand the } \\
\text { situation. Responses are } \\
\text { inappropriate. } \\
\text { UNETHICAL and } \\
\text { unacceptable behaviour. }\end{array}$ & $\begin{array}{l}\text { Minimal } \\
\text { comprehension of the } \\
\text { situation. Most } \\
\text { responses are } \\
\text { inappropriate, SOME } \\
\text { actions are unethical. }\end{array}$ & $\begin{array}{c}\text { Generally acceptable } \\
\text { understanding of the general } \\
\text { situation, acceptable } \\
\text { understanding of sub-issues. } \\
\text { Some responses } M A Y \text { not be } \\
\text { entirely appropriate } B U T \\
\text { acceptable. }\end{array}$ & $\begin{array}{c}\text { ABOVE AVERAGE } \\
\text { understanding of the general } \\
\text { situation, understands sub- } \\
\text { issues. All responses are } \\
\text { appropriate but NOT entirely } \\
\text { the best actions that should } \\
\text { have been taken. }\end{array}$ & $\begin{array}{c}\text { EXTENSIVE E EXCELLENT } \\
\text { understanding of the } \\
\text { situation including all sub- } \\
\text { issues. Provides excellent, } \\
\text { acceptable and appropriate } \\
\text { responses. BEST actions } \\
\text { taken. }\end{array}$ \\
\hline
\end{tabular}

ACCEPT

ACCEPT WITH RESERVATIONS*

DO NOT ACCEPT*

\section{COMMENTS:}

*Please provide short explanation in COMMENTS portion, if possible. Thank you! 


\section{Discussion}

An admissions protocol was developed utilizing the Multiple Mini-Interview (MMI) format. It consists of 6 main domains in separate stations, each evaluating both cognitive and non-cognitive skills of an applicant that are not adequately assessed at present from the traditional personal type of interview. Selected domains deemed important for a career in the health sciences include: Honesty, Teamwork, Respect for Authority, Time management, Ethical Behavior on the Use of Emerging Technologies and Ethical Behavior in Dealing with the Pharmaceutical Industry. The MMI attempts to eliminate the effect of chance and interviewer biases by identifying specific points of discussion and ratings are given independently by the Interviewer assigned in each domain station.

Each station describes a situation that will extensively assess each domain. Specific objectives are enumerated and points of discussion or "probes" are identified to guide the interviewer. Additional related issues may also be raised and expounded. Although communication skills may still play a role in the final assessment, applicants however, are evaluated on the soundness of their responses and appropriateness of actions toward the situation.

There are a number of explanations for the effectiveness of situational interview, namely: the situation depicted in each station was derived from actual work-related occurrence, a high face validity because all questions asked are job-related and thus increases the motivation of the interviewee to take the test seriously ${ }^{2}$, behavior not traits are being evaluated which is a concrete action that the interviewee would demonstrate given the specific situation occurring on-the-job, the entire process dilutes the effect of chance and examiner bias. ${ }^{4}$

In the development of situational interview for preresidency assessment, it is important that specific personal qualities relevant to the practice of profession be identified.5,6 However, an important challenge to this would be in carefully selecting the most important qualities and how these will be taken into consideration by the evaluators. $5,6,7$ The steps extensively outlined attempt to accurately assess the capability of prospective residents in carrying out the tasks once accepted into the program. 8,9 This type of interview measures more accurately the defined and expected behavioral patterns of residents. ${ }^{10}$

A temporary evaluation system was devised pending validation of the tool. Evaluation is a 5-point graded response that takes into consideration the interviewee's understanding and appropriateness or acceptability of responses and whether the actions taken are ethical or not. Interviewers, however, were instructed that the itemized probes and additional issues to consider should only guide them in scoring the applicant. Similarities in responses may indicate that anticipated responses were accurately predicted and thus may represent an "appropriate" behavior.

\section{Conclusion}

The inability of the traditional personal interview to evaluate professionalism competency has led to the development of a structured situational interview or the Multiple Mini-Interview (MMI) system. MMI allows for the adequate evaluation of characteristic domains deemed important for a career in the health sciences namely honesty, teamwork, respect for authority, time management, ethical behavior on the use of emerging technologies and in dealing with the pharmaceutical industry. Each professional behavior is carefully assessed in a station that is contextspecific or situation dependent. A temporary 5-point evaluation system is also developed to measure the appropriateness and acceptability of the interviewee's responses/behavior.

\section{References}

1. Hofmeister M, Lockyer J, Crutcher R. The acceptability of the Multiple Mini Interview for resident selection. Fam Med. 2008; 40(10):734-40.

2. Latham GP, Saari LM, Pursell ED, Campion MA. The Situational Interview. J Appl Psychol. 1980; 65(4):422-7.

3. Eva KW. On the generality of specificity. Med Educ. 2003; 37(7):587-8.

4. Eva KW, Rosenfeld J, Reiter HI, Norman GR. An Admissions OSCE: the Multiple Mini-Interview. Med Educ. 2004; 38(3):314-26.

5. Albanese MA, Snow MH, Skochelak SE, Huggett KN, Farrell PM. Assessing personal qualities in medical school admissions. Acad Med. 2003; 78(3):313-21.

6. Buchner LM. Increases in interrater reliability of situational interviews as a function of the number of benchmark answers. Appl HRM Res. 1990; 1(2):27-31.

7. Lynch DC, Pugno P, Beebe DK, Cullison SW, Lin JJ. Family practice graduate preparedness in the six ACGME competency areas: prequel. Fam Med. 2003; 35(5):324-9.

8. Sade RM, Stroud MR, Levine JH, Fleming GA. Criteria for Selection of Future Physicians. Ann Surg. 1985; 201(2):225-30.

9. Gayed NM. Residency directors' assessment of which selection criteria best predict the performances of foreign-born foreign medical graduates during internal medicine residencies. Acad. Med. 1991; 66(11):699-701.

10. Arvey RD, Campion JE. The Employment Interview: A summary and review of recent research. Pers Psychol. 1982; 35(2):281-322. 